\title{
Олег Донских
}

\section{НАЦИОНАЛЬНАЯ ФИЛОСОФИЯ В ГРАНИЦАХ ЖАНРА}

В понятии «национальная философия» скрыто глубинное противоречие, мгновенно осознаваемое при попытке вычленить собственно национальное в рамках общефилософского дискурса. Сравним в этом отношении философию с искусством. Возьмем литературное наследие Античной Греции: оно вырастает на национальной почве и, соответственно, реализует национальное начало как в тематическом отношении, так и в способах предъявления. Здесь свои мифология и история, своя организация текстов, место и время их манифестации, ожидания публики. Может быть, наиболее полно это выражено в трагедии с ее тематизацией, ее ролью в дионисийских торжествах и т.д. Но укорененность в своей культуре ни в коей мере не мешает греческой трагедии нести общечеловеческое содержание при переводе на другой язык и постановке на чуждых подмостках. Более того, именно эта укорененность в собственной культуре и обеспечивает ту компоненту содержания, которая переживается зрителем, принадлежащим к другой культуре. В то же время при воспроизведении национальных образцов в других условиях, в рамках других традиций происходит переосмысление этих образов. А «общечеловеческое» оказывается фиктивным пересечением национальных традиций.

Философия в такой же мере является продуктом национальным: она рождается в определенных историко-социальных условиях и формируется как выражение интересов и традиций определенного общества. И набор общих понятий, в которых происходит философствование, оказывается уникальным. Достаточно сравнить набор категорий греческой, китайской и индийской философии. Можно ли сопоставить такие понятия как «бытие», «дао» и «брахман»? У Парменида «бытие» противостоит «ничто» - «Можно лишь то говорить и мыслить, что есть; бытие ведь Есть, а ничто не есть: прошу тебя это обдумать» [Фрагменты, 1989: с. 296]. И в совершенно другом ключе бытие-дао понимается в «Дао де цзин» - «...бытие и небытие порождают друг друга, трудное и легкое создают друг друга, длинное и короткое взаимно соотносятся, высокое и низкое взаимно определяются, звуки, сливаясь, приходят в гармонию, предыдущее и последующее следуют друг за другом» [Древнекитайская... 1972: с. 115]. И как с этим сопоставить то, что мы встречаем в Упанишадах? «Источник действий - атман, ибо из него возникают все действия. Он для них общий, ибо он общий для всех действий. Он - их Брахман, ибо он носитель всех действий. Эти трое вместе суть одно - этот атман. Атман, будучи единым, тройственен» [Древнеиндийская..., 1972: с. 144-145]. А толкование понятия «брахман»

\footnotetext{
() О. Донских, 2014
} 
Радхакришнаном хотя и несколько сближает (по привычности слов в переводе) его с «дао», в любом случае относит к существенно отличному пониманию. Так, он пишет, что Брахман «являет собой наиболее полное и наиболее реальное бытие. Это живой динамический дух, источник и вместилище безгранично разнообразных форм реальности. Различия, вместо того чтобы исчезнуть как иллюзорные, преобразуются в высшую реальность» [Радхакришнан, 1993: с. 128-129]. А если сравнивать комплексы понятий, то мы обнаруживаем глубоко разные, никак не сводимые друг к другу семантические поля и, соответственно, опорные пункты философствования.

Ситуация усложняется еще и тем, что само по себе сравнение может служить лишь намеком на существо дела, поскольку мы воспринимаем эти переводные понятия в контексте нашего собственного понимания, определяемого той традицией, к которой мы принадлежим здесь и сейчас, и тем языком, который мы используем. Иначе говоря, мы воспринимаем другие культурные образцы лишь в рамках собственной культуры, и это дает совершенно разные ассоциативные и понятийные ряды. Встать же на позицию Бога, чтобы объективно сравнить культуры, нам не дано.

Принимая во внимание эти соображения, очевидно, что существует лишь национальная философия, и другой быть не может. А это, в свою очередь, означает, что появление традиции философствования начинается не с переводов чужих текстов, а с практики философствования, спровоцированной либо этими текстами, либо обучением на других языках.

Следует также отметить еще один принципиальный момент - при разговоре о традициях часто начало философии уводят к житейской мудрости, и тогда оказывается, что, например, отечественная философия родилась еще в XI веке, и ее появление отмечено такими произведениями, как «Слово о законе и благодати» митрополита Иллариона ${ }^{1}$ или «Изборником Святослава». Можно встретить утверждения о том, что «...Типичным для древнерусской эпохи являлось стремление к всеобъемлющему охвату действительности. Все вещи и явления было принято рассматривать одновременно как бы под разными углами зрения. В таком подходе тесно переплетались между собой идеи и представления, которые по привычным критериям можно было бы отнести к сфере онтологии, гносеологии, этики, эстетики, историософии. Одно дополнялось другим, представляя синкретическое нерасчленимое целое. Спрессованность смыслов усиливалась соединением христианства с элементами восточнославянского язычества» [История..., 2001: с. 12]. Больше того, философию начинают возводить к IX веку, к деятельности просветителей славян Кирилла и Мефодия. И дается такое определение философии: «С философией отождествлялись как рационализированное богословие, так и мирская мудрость, которые не противопоставлялись одно другой, а взаимно дополняли друг друга, с тем чтобы служить осознанному нравственному выбору, приближающему человека к Богу» [там же, с. 9]. Думается, что подобные рассуждения и оценки не верны по ряду причин, главные из которых следующие: 1) их авторы отождествляют наличие текстов определенного содержания с наличием традиции; 2) такой подход строится на ретроспекции - когда мы уже знаем, что такое философия, мы начинаем видеть

\footnotetext{
${ }^{1}$ См. напр. «Русская философская мысль зародилась в эпоху расцвета Киевской Руси. Большую роль здесь сыграло принятие Русью христианства в 988 г. и укоренение православной веры» [Философия, 2004: с. 79; см. также Лавриненко, Ратников, 2010].
} 
философское начало далеко за ее пределами. Но 3), и это самое главное: никакого собственно философского развития, т.е. перехода к систематической рефлексии не произошло. В отличие от литературного развития, которое в Древней Руси достигло высокой степени зрелости. Философствование как таковое не стало фактом русской жизни. Вече не стало агорой, и если бы русский Сократ вздумал обсуждать на торговой площади проблему общих понятий, в нем в лучшем случае увидели бы незлобивого юродивого.

Ведь для того, чтобы возникла и получила развитие определенная традиция, необходимы три элемента: (1) сообщество философствующих, (2) наличие аудитории, способной их воспринимать в соответствующем контексте, (3) язык, позволяющий обсуждать проблемы на категориальном уровне. В XI веке не было ни одного из этих элементов. При таком подходе очевидно, что наличие текстов (а были даже переведены отрывки из Платона и Аристотеля [Thomson, 1993]) в лучшем случае указывает на то, что были образованные люди, способные их читать в контексте своего понимания христианской мудрости и мудрости народной, бытовой. И произошло ровно то, что и могло произойти - то, что через Византию и Болгарию добралось до Руси из античного философского наследия в виде отрывков и вставок, растворилось в нефилософских жанрах. Это и летописи, и сборники афоризмов, и житийная литература, и т.п. Большой популярностью пользовался сборник «Пчела» ${ }^{2}$, в который вошли, в частности, высказывания Диогена, Сократа, Пифагора, Аристотеля, Эпикура. («Аристотель рече. Думы нъсть ничтоже ино, но оскудънье ума. Невъдуще бо, что подобаеть створити, или - ни, того ради и думаемъ; воля бо когождо не въдасть смотрити, яже подобаеть» [Пчела, 2006-2011] $]^{3}$ ). И здесь же оратор Гиперид - «Двоея дьля вины человђци от правды отступають - или страха ради, или срама ради» [там же $]^{4}$. Подобные высказывания шли в контексте учительной литературы, подобно басням Эзопа в античности. Тогда как философские жанры не дали всходов на новой почве, жанры литературные расцвели и дали такие шедевры, как «Повесть временных лет», «Житие Феодосия», «Киево-Печерский патерик», «Слово о полку Игореве»... Здесь мы можем зафиксировать и наличие писателей (Нестор, митрополит Илларион, Лука Жидята, Владимир Мономах, Кирилл Туровский и др.), наличие читающей аудитории - монахи, образованные миряне; и наличие богатого выразительного языка, в этом случае сыграли роль как книги, пришедшие из Болгарии, так и серьезная переводческая традиция, позволившая осваивать византийское письменное наследие, обогащая язык кальками и прямыми переносами греческих слов.

Следует заметить, что уникальным фактом истории античной философии является то, что при всей любви греков к классификации, в том числе классификации жанров, философия оказалась представленной разными жанрами, включая поэмы, письма, афоризмы, диалоги и др. [Донских, 2014]. В древнерусскую литературу брызги философской мысли попали лишь в сборники афоризмов, послания и другие виды сочинений. Ни диалог, ни диатриба, ни беседа, где были бы представлены собственно философские рассуждения, до нас не дошли.

${ }^{2}$ Сборник этот появился на Руси, «видимо, в конце XII в.» и представлял собой «перевод двух сборников - Иоанна Стовейского (V в.) и Максима Исповедника (VII в.), объединённых монахом Антонием (XI в.)» [Гудзий, 1976: с. 16].

${ }^{3}$ Аристотель сказал: «Советы не что иное, как оскуденье ума. Ибо, не зная, что следует делать, а что - нет, оттого и просим совета; мненье другого не дает нам решить, как следует».

${ }^{4}$ «По двум причинам люди от правды отходят - или страха ради, или позора». 
В то же время к XVI веку в русском языке постепенно сформировался слой абстрактно-богословской лексики, однако он не был представлен в специальных жанрах. Вырабатывается набор общих понятий, которые определяют основную тематизацию отечественного менталитета - в первую очередь это «правда», «воля», «мир» и «свет». Стоит обратить внимание на ту особенность этих понятий, что все они несут по два одинаково важных значения, и такая бинарность вряд ли является делом случая. «Правда» - истина и справедливость, «воля» - свобода и внутренняя сила, «мир» вселенная и отсутствие войны, «свет» - мир и сияние. Эти слова вписываются в семантическое поле, организованное вокруг понятия Бога, и приобретают соответствующие коннотации. Но это происходит вне философского дискурса в рамках литературных жанров. И, естественно, их анализ ни в коем случае не оказывается самоцелью, как это было бы в рамках философии.

Например, в своем послании св. Кирилл Белозерский говорит: «Воспоминаимъ, господине, надежду будущаго вька и царство небесное, радость святых и веселие съ аггелы, надо всьми же зрьние пресладкаго лица Божиа: То бо воистинну доброта неизреченная, весь сладость и желание и любовь несытая всьмъ любящим Его и творящим пречистую волю Его» [Кирилл Белозерский, 2006-2011] ${ }^{5}$. Здесь словосочетание «воля Божия» является обычным клише. Но уже через век, на рубеже XVXVI вв., активно обсуждается проблема свободы воли. И в дополнение к «Божией воле» появляются воли человеческие с их самовластием. Федор Курицын начинает свое «Лаодикийское послание» словами: «Душа самовластна, заграда ей в Бра (Душа самовластна, ограда ее - вера)» [Курицын, 2006-2011]. Заслуживает внимания комментарий Я. С. Лурье к этому месту: «Вера в самовластие души (свободу воли) не противоречит ортодоксально-церковным воззрениям; представление о свободе воли было основой идеи об ответственности человека за его грехи. Однако специальное подчеркивание тезиса о “самовластии” у ряда авторов XV-XVI вв. вызывало возражение официальных идеологов (“Валаамская беседа”, послания королю Сигизмунду II Августу, сочиненные Иваном Грозным), настаивавших, что в мире, со времен Адама, “везде несвободно есть”. В близком к “Лаодикийскому посланию” памятнике, "Написании о грамоте", воплощением “самовластия" объявлялась "грамота": “грамота есть самовластие, умнаго волное разумение”» [Лурье, 2006-2011]. О свободе воли говорит и св. Нил Сорский в своих посланиях, когда замечает, что некие люди хотят «по своих воляхь страстних жити, а не по святыхь писаниихъ. [...] Занеже не видятся нынь хранима жительства законъ Божиих по святых писаниих и по преданию святых отецъ, но по своих волях и умышлениих человьчьскых. [...] И егда в монастырђ съ братиами, мнящеся в повиновании, самоволием безсловесно пасутся и ошельствие такоже творять неразумно, волею плотскою ведущеся и разумомь неразсудном невЂдуще ни яже творять, ни о нихже утверждаются» [Нил Сорский, 2006-2011] ${ }^{6}$. Понятно, что до

5 «Вспоминай, господин, надежду на будущий век и царство небесное, радость святых и веселие с ангелами; надо всем же этим - лицезрение пресладкого лица Божия: Он ведь воистину красота неизреченная, весь Он сладость и желание и любовь ненасытная ко всем любящим его и творящим пречистую волю Его».

6 «Согласно своим страстным волям жить, а не по святым писаниям. [...] Потому что не видно ныне общежительства по законам Божиим, по святым писаниям и по преданию святых отцов, но только - по своим волям и умышлениям человеческим. [...] Они и в монастыре с братьями, будто бы в повиновении, в самоволии без смысла пасутся, и отшельничество также осуществляют неразумно, плотской волей ведомые и не понимая неразмышляющим разумом ни того, что делают, ни того, в чем утверждаются». 
философского дискурса здесь еще очень далеко, но тема и проблема обозначены совершенно ясно [см. также: Клибанов, 1996: с. 157 и сл.]

У св. Кирилла «правда» в основном используется в значении истины: «А в чемъ будет твоя правда пред ними, и ты, господине, за собя стой по правдъ [...] Ни сотвориши неправду на суде, яко судъ истиненъ есть; проклят всякъ неправо судя. [...] Пророкъ рече: “Ярость Господня на них неизцЊлна до вЊка, и огнь поясть нечестивыя” - мзды ради, иже неправдою взимают. Судяи праведно, без мзды, спасени будут и царство небесное насльдуют» [Кирилл Белозерский, 2006-2011] ${ }^{7}$. Эта правда-истина может быть разной - у каждого своя. Киприан пишет: «А ко Царюгоруду ьду оборонитися Богомъ и святымъ патриархомъ и Великимъ сборомъ. И тии на куны надъются и на фрязы, азъ же на Бога и на свою правду» [Митрополит Киприан, 2006-2011] ${ }^{8}$ В этом же значении слово «правда» встречается примерно в то же время в «Послании мудрого Феофана монаху Прохору»: «Два бо пути есть разума: ли глаголати, или молчати правъ. Мнози философи быша в миру, но двъ главъ быша философом Платонъ и Пифагоръ. Овъ бо благоулучно повъствовал, овъ же благословесно умолча» [Послание мудрого..., 2006-2011] .

Однако уже у св. Нила Сорского правда несет значение истины-справедливости: «И се есть знамение любве Божиа, еже скорби принесутся кому о дълании правды» [Нил Сорский, 2006-2011] ${ }^{10}$. Андрей Курбский наряду с правдой-истиной употребляет слово «правда» в значении закона и справедливости: «Ибо зЂло похвально словеству навыкати и дњиствовати, ижебы оброняти правду» [Курбский, 2006-2011b] ${ }^{11}$. «...Отомщения на тя просят, заточенныя же и прогнанныя тобою без правды от земля Богу вопиют на тя день и нощь!» [Курбский, 2006-2011a]. «Зри, о царю, со прилежаниемъ: аще поганские философи по естественному закону достигли таковую правду и разумность со дивною мудростию между собя, яко апостоль рече: “Помыслом осуждающим или оставляющим”, а того ради и всею вселенною попустил Богъ имъ владъти, а мы християне нарицаемся, а не токмо достигаемъ книжников и фарисеов правды, но и человьков, естественным законом живущих!» [Курбский, 2006-2011с $]^{12}$. Обращает на себя внимание упоминание естественных законов, что безусловно свидетельствует о западноевропейском влиянии.

${ }^{7}$ «Не сотвори неправду на суде, ибо суд должен быть истинным; проклят всякий неправедно судящий. [...] Пророк сказал: “Ярость Господня на них неисцелима до конца века, и огонь поест нечестивых” - из-за мзды, которую они неправедно взимают. Судящие праведно, без мзды, спасены будут и царство небесное наследуют».

${ }^{8}$ «А я в Царьград еду обороняться Богом, святым патриархом и Великим собором. И те на деньги надеются и на фрягов, я же на Бога и на свою правду».

9 «Два ведь пути есть у разума: либо говорить, либо быть правым, молча. Много философов было в мире, но две вершины были среди философов - Платон и Пифагор. Один благополучно повествовал, другой же благословесно замолчал».

10 «И это знак любви Божией, - когда скорби достаются тому, кто поступает по правде».

11 «Изучать красноречие и использовать его, чтобы отстаивать истину - это весьма похвально».

12 «...Взывают об отомщении тебе, заточенные же и несправедливо изгнанные тобой из страны взывают день и ночь к Богу, обличая тебя» Посмотри же, царь, со вниманием: если языческие философы по естественным законам дошли до таких истин и до такого разума и великой мудрости между собой, как говорил апостол: “Помыслам осуждающим и оправдывающим", и того ради допустил Бог, чтобы они владели всей вселенной, то почему же мы называемся христианами, а не можем уподобиться не только книжникам и фарисеям, но и людям, живущим по естественным законам!» 
А уже в начале XVII века в текстах встречаются и фрагментарные сравнения разных философских подходов. Так, в сочинении «О причинах гибели царств» автор пишет: «Наперед показуютца двух мудрецовъ слова или разумънья о томъ, будуть всякие царства с вины и причины человъческие погибель свою и разоренье приемлют или судомъ Божиим. Платон философъ тьми словы о том написал, что коли прироженные и естественные начала свое всякое царство имъетъ, хотя бы и налутчи и крђпко постановленое и устрою не было, и оно своего времъни за дълами и за розъправами своими, сирђчь от перемены закону, погибнеть. Ксенефонть философ написаша о дълах царя перскаго Кируса, смотрячи на всъ царства, которые коли-нибудь любо под одного царя, любо под многих царей властью были, дивитца тому, что ни одиное царство цьлое и долгимъ временемъ безстрашное не стояло, и показуетъ тому такую вину, сирьчь тьх люди, которые властельми и начальниками государствъ бывают, егда за их злобою и за их хотьниемъ и гордостью, и за их неправдою всякие царства переменяютца и погибают. И с того сугубого разумЂния тъхъ двухъ философ лутчее и праведное есть Ксенефонта мудреца разумьние того для, что хотя не дълаетца ничто на свЂте без воли и без суда Божия, совершение того суду Божия исполняетца за грехами и злобами человьческими, которые дьлают люди, розлучаяся з Богом, и гневъ его страшны на себя попускаютъ, который ничим, толко покаянием, усмиряетца» $[\text { О причинах..., 2006-2011 }]^{13}$. Автор очевидно вписывает спор древних философов в контекст соотношения человеческого самовластия и Божией воли, что несомненно продолжает более раннюю традицию.

Это еще далеко не философствование, но, как и с проблемой самовластия души, мы видим ясное обозначение темы с использованием абстрактной лексики.

Приведенные примеры лишь пунктирно указывают на процесс постепенного углубления, обогащения и прояснения определенных семантических полей. Так, «понятие воли в той грозди значений, как она развилась в русской культуре, особенно в тесном взаимодействии с такими понятиями, как правда и мир, приобрела значение идеала. Но идеала лишь в том случае, если воля реализует высшую правду в рамках мираобщины, а это практически невозможно. Она, к сожалению, слишком часто самовластно выламывается из этих рамок, разбивается на отдельные волевые устремления, совершая тем самым грех отпадения (и это всегда внутри сознания). И, не уважая - это чисто русская особенность - закона как земного установления, она упивается возможностью прорываться за любые пределы, но уже не может вернуться ко все еще живущей в ней изначальной полноте единой правды, находящейся слишком высоко. И при

13 «Прежде всего приводятся изречения и суждения двух мудрецов о том, почему приходят различные царства к гибели и разорению: люди ли тому виной и причиной или же суд Божий. Платон-философ писал об этом так: каждое царство имеет свои исконные и естественные основы, но каким бы ни было оно прекрасным и могучим и устроенным, все равно погибнет в свое время из-за дел и распрей, то есть от перемены законов. Ксенофонт-философ в описании деяний персидского царя Кира, обозрев разные царства, существовавшие либо под властью одного царя, либо многих властителей, удивлялся тому, что ни одно из них не просуществовало в целости и безопасности долгое время, и считал, что причиной тому люди, бывшие властителями и правителями этих государств: из-за их злобы, притязаний, гордости и неправедных дел происходят перемены во всех царствах и они гибнут. Из двух мнений тех двух философов лучше и справедливее мнение мудреца Ксенофонта: хотя и не происходит ничего на свете без воли Бога и без суда его, вершится этот суд Божий за грехи и преступления, совершаемые людьми, отпавшими от Бога, и навлекают они на себя его страшный гнев, который ничем не отвести, кроме покаяния». 
этом, естественно оправдывая себя, только сильнее и глубже утверждает себя в отпадении. Все это делает сознание носителя воли более свободным, чем в культурах, проникнутых римским правом с его уважением к закону, но в то же время делает бунт безгранично отчаянным и страшным» [Донских, 2005: с. 73-74]. Именно такое понимание оказывается естественным для национального менталитета.

Важной чертой отечественного менталитета явился его историзм, сформировавшийся в несколько этапов, начиная с киевского периода. Его появление связано с христианской историографией, когда события вписываются в матрицу христианской истории. Русские князья отстаивают православные земли от язычников и сравниваются с раннехристианскими святыми. Известно, что русские летописи являются переводами византийских хроник, собственно новое начинается, когда они описывают именно русскую историю. Но при этом принципиально важно отметить их высокое литературное качество, что свидетельствует не только о самостоятельности, но и о творческом отношении. Москва унаследовала от Киева живое чувство исторической преемственности и утвердила это чувство в известной теории «Москва Третий Рим». С.А. Зеньковский показывает, что после образования Московского патриархата эта теория, будучи ранее достоянием высшего духовенства, становится частью национального сознания. Она утверждает острое чувство истории в ключе мессианства, что позже развивается мыслителями славянофильского направления [Зеньковский, 1995: с. 39-40]

Можно утверждать, что названные выше темы определяют формирование национальной философии. Два течения мысли формируют возможность философствования как систематической рефлексии - влияние образованного епископата украинского происхождения, назначаемого на протяжении XVIII века на российские кафедры. «...Стефан Яворский был первым архиереем, назначенным Петром из малороссиян. И царь-реформатор придал этому случаю принципиальное значение. Он положил начало целой системе, на ряд десятилетий, - передачи русской церкви в руки киевских ученых именно потому, что они были школьно подготовлены и по методам западноевропейской латинской школы. Петру казалось, что через этих церковных западников русская церковь перестанет быть ему тормозом в насаждении западного просвещения и западного типа реформ» [Карташев, 1959: с. 330]. Вторая линия определилась постепенным европейским просвещением самих великороссийских дворян. К концу XVIII века русский язык обогатился абстрактной лексикой, появились образованные люди, однако из трех условий возникновения философии не было ни творческой философствующей группы, ни аудитории, способной и желающей их воспринимать. Немногочисленные университетские и лицейские преподаватели и их слушатели осваивали немецкую философию, которая мало интересовала публику вне учебных стен.

Кроме того, в первой трети XIX века большую роль сыграл романтизм, который направлял мысль на выявление особенностей национального духа. Романтизм вдохновил русскую мыслящую публику на прояснение национальных ценностей и понятий, что заложило основу для собственно философской рефлексии. Но происходит это не в форме трактатов, а, в первую очередь, в литературных произведениях и по поводу литературных произведений, как это было в спорах Шишкова с Карамзиным и их сторонников.

И только во второй трети XIX века (когда, по словам Н. Лосского, «русское общество уже пережило увлечения немецким идеализмом Канта, Фихте, Шеллин- 
га и Гегеля» [Лосский, 1991: с. 24] формируются группы философствующих и желающих их слушать. Именно здесь и выступает на первый план вопрос жанра. Философствование по западным (преимущественно немецким) образцам не позволяет сформировать философскую традицию в силу его чисто академического характера.

В этом отношении очень показательна эволюция взглядов А. С. Пушкина ${ }^{14}$. В свое время часто утверждалось, что Пушкин исповедовал передовые (антимонархические и т.п.) взгляды и был близок к декабристам. Однако более пристальный анализ показывает, что он в своем мировоззрении двигался в противоположном направлении от идеологии французского просвещения и гедонистического героизма к христианству [Лесскис, 1993: с. 367 и далее]. Его мышление исторично в том смысле, что он рассматривает русскую историю как процесс, не считая ни одну эпоху образцом (что отличает его от славянофилов), но этот же подход не дает ему с легкостью принять либеральные взгляды: он скептически относится к возможности переделать общество по определенной извне взятой модели. И в этом Пушкин смыкается с Н. М. Карамзиным, который представил свои консервативные взгляды в «Записке о древней и новой России». Пушкин много размышляет о роли церкви, отводя ей крайне важную роль в формировании духовной культуры народа. В своих болдинских сочинениях он показывает, что моральный кризис современного общества вызван приверженностью к гедонистическим принципам (мы бы сказали сейчас о «потребительском обществе»).

Что касается понимания «правды», то Пушкин двигается от «правды-истины» через определенное понимание «чести» как личной правды к пониманию правды как высшей истины и социальной справедливости. Она устанавливает абсолютные цели и стандарты. Не менее показательно его представление «воли». От политической свободы ранней поэзии представления Пушкина эволюционируют к вольности как совершенной внутренней свободе, ясно выраженной стихотворением «Из Пиндемонти».

От споров шишковистов и карамзинистов первой четверти века происходит переход к обсуждению философских проблем в жанре писем (П. Я. Чаадаев), литературной критики (И. В. Киреевский, Н. И. Надеждин, В. Г. Белинский), позже дискуссий историков о судьбах России (М. Н. Погодин и Н. И. Костомаров). Выявление специфики отечественного исторического пути оказывается проблемой, живое обсуждение которой приводит к собственно философской рефлексии.

Надо заметить, что таким же образом формировались и другие философские традиции: «B XVIII и самом начале XIX в. таким же образом строилась немецкая философия, мыслившая себя органом национального самосознания». В системах Канта, Фихте и Гегеля «оптимистически соединяются социальная и историческая аксиология...» [Ивонин, Ивонина, 2013: с. 5]. Отличие от русского интеллектуального развития состояло в том, что в Германии огромную роль играет гимназическая и университетская традиция, в рамках которой философские трактаты были обычным делом. Русская же философия наиболее полное выражение сперва получает в литературных журналах, а не в трактатах, написанных по немецким образцам, хотя, конечно, влияние Шеллинга и Гегеля огромно. Не случайно письма Чаадаева написаны по-французски - он обращается к образованным

${ }^{14}$ CM. «Pushkin's worldview» in: [Donskikh, 2009: p. 152-178.] 
дворянам. Именно они составляли аудиторию, способную участвовать в философском дискурсе. А уже для популяризации его идей «Философическое письмо» было переведено на русский.

Чаадаев печатается в литературно-общественном журнале «Телескоп», где появляются статьи по литературе, философии, экономике и т.д. Там же печатались А. С. Хомяков, А. С. Пушкин, В. Г. Белинский, Ф. И. Тютчев, С. П. Шевырев, М. П. Погодин и др. И. В. Киреевский издает журнал «наук и словесности», где в программной статье «Девятнадцатый век» говорит о том, что в это время соединяются жизнь и литература, в особенности в ее поэтической форме: «Именно из того, что Жизнь вытесняет Поэзию, должны мы заключить, что стремление к Жизни и к Поэзии сошлись, и что, следовательно, час поэта Жизни наступил» ${ }^{15}$. Философия в этом движении не играет самостоятельной роли. Так, князь В. Ф. Одоевский, говоривший о «пропасти» всего написанного для этого журнала, был и философом-любомудром, и писателем, и литературным критиком. Близок к журналу был наш замечательный поэт-романтик В. А. Жуковский. Не случайно именно в круге литераторов, объединенных журналом Киреевского, начало оформляться славянофильское направление, которое было нацелено на выявление особенности отечественного менталитета. Сам Киреевский занимается древнерусскими рукописями, а его брат Петр собирает народные стихи и песни.

Не говоря уже о собственно славянофилах и их творчестве (программная поэзия И. С. Аксакова и А. С. Хомякова), в причастности к этому интеллектуальнолитературному движению формируются взгляды Ф. И. Тютчева, Ф. М. Достоевского и Л. Н. Толстого. И в одном из первых (если не в первом) очерке собственно национальной философии Э. Л. Радлов говорит о двух наших величайших романистах как о выразителях славянофильской и западнической тенденций русской мысли.

В. С. Соловьев, философ per se, начинает свою творческую деятельность с трактатов в немецком стиле, но именно эти работы имеют меньшее значение, чем его публичные лекции о Богочеловечестве, стихи, в которых так или иначе выражает собственно философские представления, и статьи в толстых журналах. В последние годы жизни он вступает в жесткую полемику со Львом Толстым из-за его учения о непротивлении злу насилием. И пишет свои «Три разговора». Сам факт противостояния писателя и философа как стоящих на одном уровне, весьма показателен. Значительное влияние на Соловьева оказала и сложившаяся в Киеве философская школа, представитель которой П. Д. Юркевич стал первым назначенным в Московский университет профессором, не проходившим ранее стажировки в Германии. Темы, которые он развивал в духе христианской антропологии (особенно его работа «Сердце и его значение в духовной жизни человека»), шли в русле национальной интеллектуальной традиции во многом благодаря единым православным корням. Именно поэтому его работы и вызвали такое отторжение со стороны атеистически настроенных западников.

В российской интеллектуальной жизни в принципе не возникает противостояния философии и поэзии, характерной, например, для английской традиции. Здесь можно вспомнить У. Блэйка с его откровенной ненавистью к Ньютону и Локку как представителям «Разума» в противоположность «Воображению». Он говорит о

${ }^{15}$ Европеец. - 1832. - № 1. - С. 15, цит. по [Журова, 2001]. 
разуме («Уризене» его персональной мифологии), который манифестируют Локк и Ньютон: «Когда философия пяти чувств была завершена, Уризен взвыл и передал ее в руки Ньютона и Локка» ${ }^{16}$. И Разум (Философия) начал войну против Воображения: «Абстрактная философия с ненавистью воюет с воображением (которое есть божественное тело господа Иисуса, благословенное навеки)» ${ }^{17}$.

В этом же ключе, хотя и более рассудочно, представляет противоположность философии и поэзии Перси Биши Шелли: «Разум увеличивает количество качеств уже известных; воображение воспринимает ценность этих качеств, как по отдельности, так и в целом. Для разума важны различия, для воображения - сходства вещей» ${ }^{18}$.

Для А. А. Блока, напротив, разум и чувства дополняют друг друга, а не противопоставляются:
Но ты, художник, твердо веруй
В начала и кониы. Tыз знай,
Где стерегут нас ад и рай.
Тебе дано бесстрастной мерой
Измерить всё, что видишь тыл.
Твой взгляд - да будет тверд и ясен.
Сотри случайные черты -
И ты увидишь: мир прекрасен.
Познай, где свет, - поймешь, где тьма.
Пускай же всё пройдет неспешно,
Что в мире свято, что в нем грешно,
Сквозь жар души, сквозь хлад ума

[Блок, 2010].

Для российского менталитета такого разрыва не существует. Можно говорить о взаимообогащении. Не случайно такое значение приобрел Ф. М. Достоевский. Практически у всех национальных философов, начиная с В.С. Соловьева, есть статьи и книги о его творчестве как выражении национального сознания ${ }^{19}$. К. Н. Леонтьев - замечательный писатель и эссеист. Весьма малую известность снискала первая, написанная в гегельянском духе, работа В. В. Розанова, блестящего стилиста «О понимании. Опыт исследования природы, границ и внутреннего строения науки как цельного знания». Зато поздние размышления в виде дневниковых записей, эссе, заметок по случаю, диалогов, собранные в сборниках «Уединенное» и «Опавшие листья», явились значительным вкладом в отечественную литературу и философскую традицию.

В известном смысле Россия в своем философском развитии проходит путь, аналогичный античной мысли (с одной поправкой, что она научилась систематической

${ }^{16}$ «Till a Philosophy of Five Senses was complete Urizen wept \&gave it into the hands of Newton \& Locke» [Poetry..., 1948: p. 248].

17 «Abstract Philosophy warring in enmity against Imagination (Which is the Divine Body of the Lord Jesus. blessed for ever)» [Ibid., p. 437].

${ }^{18}$ «Reason is the enumeration of qualities already known; imagination is the perception of the value of those qualities, both separately and as a whole. Reason respects the differences, and imagination the similitudes of things» [Shelley, 1993-2014].

19 О философском значении творчества Достоевского сравнительно с Толстым см. [Донских, 2006]. 
рефлексии у немецких мыслителей): она осуществляет философствование по большей части вне университетских философских курсов, в самых разных жанрах от стихов и романов до писем, диалогов и трактатов. Именно в них, а не в трактатах, построенных по научным образцам, демонстрируются результаты рефлективных размышлений. И эти трактаты, которые все же присутствуют в отечественной культуре, явно играют существенно меньшую роль, чем в западноевропейской философской традиции.

Отдавая полный отчет в некоторой обрывочности представленных соображений, я полагаю, что национальная традиция, в частности такая, в рамках которой сформировалась систематическая рефлексия, вполне может и должна быть предметом точного исследования. Ее развитие можно проследить, во-первых, по текстам, в частности по признакам формирования абстрактной лексики, свидетельствующей о наличии рефлективной составляющей определенных семантических полей; вовторых, по связанному со способами бытования текстов характеру изменения коммуникации; в-третьих, по тому, как вместе с коммуникацией меняются социальные группы и их отношения.

\section{СПИСОК ЛИТЕРАТУРЫ}

Блок А. Возмездие (07.07.2010) // Электронный ресурс. Режим доступа: http://az. lib. $\mathrm{ru} / \mathrm{b} / \mathrm{blok}$ _a_a/text_0040. shtml

Гудзий Н. К. История древней русской литературы. - Москва: Наука, 1976. - 512 с.

Донских О.A. «Между миром высшим и низшим (к вопросу о формировании категории воли в русской духовной традиции) // Сибирь на перекрестье мировых религий. Материалы Второй межрегион. конференции памяти М. И. Рижского. - Новосибирск: НГУ, 2005. - C. 67-74.

Донских О. А. Простая магия философии // Гуманитарные науки в Сибири. Серия: Философия и право. - 2006. - № 1. - С. 42-48.

Донских О. А. Философия как жанр (начало) // Методология науки и дискурс-анализ. Москва: ИФ РАН, 2014. - С. 117-140.

Древнеиндийская философия, Начальный период. - Москва: Мысль, $1972^{2} .-271 \mathrm{c}$.

Древнекитайская философия. Собрание текстов в двух томах. - Москва: Мысль, 1972. T. $1 .-363 \mathrm{c}$.

Журова Г. М. Журнал «Европеец» И. В. Киреевского - печатный орган литераторов пушкинского круга (2001) // Электронный ресурс. Режим доступа: http://www. kozelsk. $\mathrm{ru} / \mathrm{konfer} / \mathrm{c} 7$. htm

Зеньковский С.А. Русское старообрядчество. Духовные движения семнадцатого века. Москва; изд. «Церковь», 1995. - 528 с. (Репринт издания Зеньковский С. Русское старообрядчество: Духовные движения XVII века. - Мюнхен: W. Fink, 1970. - Серия «Forum Slavicum»; T. 21. -528 c.).

Ивонин Ю., Ивонина О. Миссия невыполнима? Ч. 1. Аксиология «Русской идеи». XIX век. Саарбрюккен: Palmarium Academic Publishing, 2013. - 643 c.

История русской философии: Учеб. для вузов / Редкол.: М. А. Маслин и др. - Москва: Республика, 2001. - 639 с.

Карташев А. В. Очерки по истории русской церкви. - Париж: YMKA-PRESS, 1959. - Т. 2. $576 \mathrm{c}$.

Кирилл Белозерский. Три послания и духовная грамота (2006-2011) / пер. Г. М. Прохорова // Электронный ресурс. Режим доступа: http://lib. pushkinskijdom. ru/Default. aspx? tabid $=4991$

Клибанов А. И. Духовная культура средневековой Руси. - Москва: Аспект Пресс, 1996. $367 \mathrm{c}$. 
Курбский А. Первое послание Ивану Грозному (2006-2011a) / подг. текста Ю. Д. Рыкова, пер. О. В. Творогова, комм. Я. С. Лурье и Ю. Д. Рыкова // Электронный ресурс. Режим доступа: http://lib. pushkinskijdom. ru/Default. aspx? tabid=9105

Курбский А. Первое послание Кузьме Мамоничу (2006-2011b) / Подготовка текста, перевод и комментарии А. А. Цехановича // Электронный ресурс. Режим доступа: http://lib. pushkinskijdom. ru/Default. aspx? tabid $=9869$

Курбский А. Третье послание Ивану Грозному (2006-2011c) / подг. текста Ю. Д. Рыкова, пер. О. В. Творогова, комм. Я. С. Лурье и Ю. Д. Рыкова // Электронный ресурс. Режим доступа: http://lib. pushkinskijdom. ru/Default. aspx? tabid=9113

Курищын Ф. Лаодикийское послание (2006-2011) / пер. и комментарий Я. С. Лурье // Электронный ресурс. Режим доступа: http://lib. pushkinskijdom. ru/Default. aspx? tabid $=5072$

Лавриненко В.Н., Ратников В. П. Философия: учебник для вузов. - Москва: ЮНИТИДАНА, 2010. $-733 \mathrm{c.}$

Лесскис Г. А. Пушкинский путь в русской литературе. - Москва: Худ. лит., 1993. - 526 с.

Лосский Н. О. История русской философии. - Москва: Высшая школа, 1991. - 559 с.

Лурье Я. С. Комментарий к «Лаодикийскому посланию» Федора Курицына (2006-2011) // Электронный ресурс. Режим доступа: http://lib. pushkinskijdom. ru/Default. aspx? tabid=5072\#_edn1

Митрополит Киприан. Послание игуменам Сергию и Феодору (2006-2011) / пер. Г. М. Прохорова // Электронный ресурс. Режим доступа: http://lib. pushkinskijdom. ru/Default. aspx? tabid $=4990$

Нил Сорский. Четыре послания и завещание (2006-2011) / пер. Г. М. Прохорова // Электронный ресурс. Режим доступа: http://lib. pushkinskijdom. ru/Default. aspx? tabid=5090

О причинах гибели царств (2006-2011) / подг. текста, пер. и коммент. М. А. Салминой, пер. O. В. Творогова // Электронный ресурс. Режим доступа: http://lib. pushkinskijdom. ru/Default. aspx? tabid=10944

Послание мудрого Феофана монаху Прохору (2006-2011) / пер. Г. М. Прохорова // Электронный ресурс. Режим доступа: http://lib. pushkinskijdom. ru/Default. aspx? tabid=4986

Пчела (2006-2011) / пер. В. В. Колесова // Электронный ресурс. Режим доступа: http://lib. pushkinskijdom. ru/Default. aspx? tabid $=4968$

Радхакришнан С. Индийская философия. В 2-х т. - Москва: МИФ, 1993. - Т. 1. - 624 с. (Репринт изд.: Радхакришнан С. Индийская философия. В 2-х т. - Москва: «Иностранная литература», 1956. - Т. 1.-623 c).

Философия. Учебник / Под ред. А. Ф. Зотова, В. В. Миронова, А. В. Разина. - Москва: Академический Проект; Трикста, 2004. - 688 с.

Фрагменты ранних греческих философов. Часть 1. - Москва: Наука, 1989. - 576 с.

Donskikh $O$. The Formation of Russian National Consciousness. (National Philosophy as a Reflection upon National Consciousness). - Köln: Lampert Academic Publishing AG \& Co, 2009. $-245 \mathrm{p}$.

Poetry and Prose of William Blake / Ed. by Jeffrey Keynes. - London: The Nonesuch Press, 1948. $-936 \mathrm{p}$.

Shelley P. B. A Defence of Poetry (1993-2014) // Электронный ресурс. Режим доступа: $\mathrm{http}: / / \mathrm{www}$. bartleby. com/27/23. html

Thomson F. J. The Corpus of Slavonic Translations Available in Muscovy // California Slavic Studies. - XVI. - V. I. - 1993. - P. 179-187.

Стаття одержана редакцією 01.02.2014 


\section{Oleg Donskikh}

\section{NATIONAL PHILOSOPHY WITHIN THE LIMITS OF GENRE}

In order to speak seriously about the emergence of national philosophy, it is necessary to consider not only the content of available texts that belong to a certain period, but also the ability of society to create and adequately perceive them. The article shows how in the Russian mediaeval national consciousness certain themes were elaborated, in particular the themes of "pravda" and "volya", which later in the XIX century determined not only the main direction of the national philosophizing, but also its genre diversity.

Oleg Donskikh, Doctor of Sciences (Philosophy), PhD (Monash, Australia), Professor, Head of Department of Philosophy at Novosibirsk State University of Economics and Management.

Олег Донських, д.філос.н., професор, PhD (Monash, Australia), зав. кафедри філософії Новосибірського державного університету економіки та управління.

Олег Донских, д.филос.н., профессор, PhD (Monash, Australia), зав. кафедрой философии Новосибирского государственного университета экономики и управления. 